\title{
A Historical Review of the Scientific and Common Nomenclature Associated with Chia: From Salvia hispanica to Salvia mexicana and Chian to Salba
}

\author{
Anacleto Sosa-Baldivia ${ }^{1,4 *}$, Guadalupe Ruiz-Ibarra ${ }^{2,4}$, Franklin Johnson ${ }^{3}$, Raúl René Robles-de la Torre ${ }^{4}$, María \\ Reyna Robles-Lopez ${ }^{4}$, Maneesh Sharma ${ }^{5}$ and Xiaozhong Liu ${ }^{5}$
}

${ }^{1}$ Nutrilite S de RL de CV. Av. México \#8, El Petacal Jalisco, Mexico.

${ }^{2}$ Instituto Tecnológico José Mario Molina Pasquel and Henriquez campus Tamazula de Gordiano, Jalisco, México

${ }^{3}$ Trout Lake Farm LLC, WA, USA

${ }^{4}$ Centro de Investigación en Biotecnología Aplicada (CIBA-IPN), Tlaxcala, México

${ }^{5}$ Amway Access Business Group, Buena Park CA, USA

Submission: September 06, 2018, Published: September 28, 2018

"Corresponding author: Anacleto Sosa-Baldivia, Nutrilite S de RL de CV. Av. México \#8. Rancho El Petacal, Municipio de Tolimán Jalisco, CP: 49750, México; Tel: 01 (341) 4135878; Email: anacleto.sosa@amway.com

\begin{abstract}
This review presents an in-depth perspective on the history of scientific nomenclature and common name change of the well-known ancient oilseed crop, Chia. Prior to the $16^{\text {th }}$ century, the chia crop was given the name:

a. Chian by the Mexica culture. Later in mid- $18^{\text {th }}$ century.

b. The botanist Pehr Löfling scientifically called Chia Salvia hispanica, which was later published by Carl Linnaeus in his Species Plantarum book. By 1832, this scientific name became well-accepted among the Spanish Language Academy.

c. Effectively replacing the Nahua term Chian by the new Spanish word Chia. During the same era in Mexico, Pablo de la Llave

d. Called it Salvia chian; and confirmed that chia did not grow in the production areas of Spain. In the $20^{\text {th }}$ century.

e. Salvia chia was assigned by the botanist Merritt L. Fernald while Nicholas I. Vavilov used this exact Latin binomial name to demonstrate that the region passing through southern Mexico and into Guatemala was the geographical origin of the chia plant. In 2006, the company Agrisalba SA in Peru bred the white chia seed phenotype using conventional methods and called it Salba. Furthermore, finally in 2012.

f. The International Plant Name Index assigned the common name Chia to the Salvia mexicana species which corrected all inconsistencies assigned to this Mexican chia ecotype since Linnaeus's work nearly 265 years ago. This internationally accepted nomenclature pays tribute to this Mexican crop with deep ancestral roots and was by consensus a means to restore its identity which without a doubt is in-line with its original significance: "A Mexican plant to cure or save."
\end{abstract}

Keywords: Salvia hispanica; Salvia Mexicana; Chia; Chian; Salba; Nomenclature; History

Abbreviations: INPI: International Plant Name Index; WCSP: World Checking List of Select Plants Families; HCBGK: Herbarium Catalogue, Royal Botanic Gardens Kew

\section{Introduction}

The domestication of crops in North America can be dated back 7,000 years, and human consumption of plants reached its peak by the time that the Mexica culture flourished in the southern region of Mexico circa 1325-1521 B.C. [1,2]. While the list of domesticated crops in Mesoamerica was found to be extensive [1,3], at the time when sea-voyaging Spaniards landed in Mexico, the food culture there was based mostly on corn, bean, chia, leafy vegetables, and pseudocereals-like amaranth and huauzontle $[4,5]$. The importance of the first two crops in Mexico as carbohydrate and protein food source, respectively, is still quite high. While Mexico alone produces more than 200 different crops for fresh and processed goods, the corn and bean crops cover $44 \%$ of the total current cultivated land [6]. Two other crops, chia and amaranth, which initially did not receive the same attention as the 
more sought-after landraces of corn, bean, cocoa, chili, pumpkin, and tomato were not so popular in most traditional and modern food cultures and diets [7]. However also, both chia and amaranth exhibit several inconsistencies that occurred in their history as a domesticated crop. According to Sosa-Baldivia et al. [8], several of the inconsistencies found in the history of chia are not only related to the time when it had emerged that the Mexican people were nearly extinct, but is a result of other erroneous notations made throughout history, and most, if not all previous assumptions of chia were accepted at a time when the knowledge base of this Mexican-Guatemala native plant was, in fact, very poor. Other irregularities found present in the literature are many listed here:

a. The use of its name as Salvia hispanica, since this incorrectly describes Chian/Chia as a native crop of Spain [9].

b. Affirmations made that its drastic reduction in the consumption was associated with an imposed ban by the Ruling Spain [10].

c. To have reported that the chia crop is an exclusive summer crop [11].

d. To have claimed that the chia crop resists the attack of pests and diseases [12].

e. To have supposed that chia has low requirements of fertilization for quality production [13].

f. To have used the term chia to refer broadly to chan (also named as "fat chia" or "Chia of Colima"), huauzontle, plantago, and amaranth crops [14-17].

g. To publish erroneous pictures of this crop [18]. h. To have changed chia's name and nomenclature many a time [9,19-22]. Regarding the last point, though all Mesoamerican crops presented changes in their nomenclature, none of them received so many name changes as the chia crop. Indeed, this action considerably had caused much confusion among academic, scientific and private research communities on the correct name(s) for chia. The objective of this review is to present a comprehensive history on the changes that have taken place in the common and scientific naming of the chia seed crop that today is readily-available on the industrial scale and widely-used by many different multi-national industries.

\section{History on the Naming Nomenclature of Chia}

Chia is a flowering plant of the Salvia genus within the family Lamiaceae which contains many aromatic herbs such as mint, rosemary, lavender and thyme to name a few [23]. Currently, all plants are scientifically assigned a Latin binomial with at least two names, or the genus and species names -the first one can be found typically associated with its common name, but if it is written in italics then this refers to the plant's genus name; while the species name is the one that botanists and naturalists assign to the plant according to its proper taxonomic classification - e.g. 'angustifolia' in Latin means narrow-leaf; and 'syriacus' can mean it originated from a certain geographical region such as the case for Hibiscus syriacus (Common name: Rose of Sharon) which has been traced back to lands within Syria [24]. In the case of the native crops of Mexico, on top of the assigned Nahua word for chia and many other reasons mentioned above, in addition to the elimination of the chia term, and then both Spanish and English words emerging and improperly used among the peoples such that chia's origin and meaning had been diluted to the point of near extinction (Table 1).

Table 1: Changes on the common and scientific nomenclature occurred at some crops domesticated on America.

\begin{tabular}{|c|c|c|c|c|c|c|c|c|}
\hline Scientific name & Year & Nahua & English & Year & Espanish & Year & Modern & Year \\
\hline Salvia hispanica L. & 1753 & Chian $^{\mathrm{Me}}$ & & & Chía & 1832 & Salba & $2006^{\mathrm{Vu}}$ \\
\hline Salvia chian $\mathrm{L}$. & 1832 & & & & & & & \\
\hline Salvia chia Fern. & 1900 & & & & & & & \\
\hline Salvia mexicana L. & 2012 & & & & & & & \\
\hline Solanum lycopersicum L. & 1753 & Xictomatl $^{\mathrm{He}}$ & Tomato & $1604^{\text {На }}$ & Jitomate & $1604^{\text {На }}$ & & \\
\hline Lycopersicum esculentum Mill. & 1754 & Tomatl $^{\mathrm{He}}$ & & $1604^{\mathrm{Ha}}$ & Tomate & $1604^{\text {На }}$ & & \\
\hline Solanum Lycopersicum L. & 2012 & & & & & & & \\
\hline Zea mays L. & 1753 & Centli $^{\mathrm{He}}$ & Corn, Maize & $i$ & Maíz & $1542^{\mathrm{Me}}$ & & \\
\hline Persea Americana Mill. & 1754 & Ahuacatl ${ }^{\mathrm{He}}$ & Avocado & $1697^{\text {На }}$ & Aguacate & $1697^{\text {На }}$ & & \\
\hline Teobroma cacao L. & 1753 & Cacauatl $^{\mathrm{Me}}$ & Cocoa & $1672^{\mathrm{Ha}}$ & Cacao & $1542^{\mathrm{Me}}$ & & \\
\hline Opuntia ficus-cactus Mill. & 1768 & Nopalli $^{\mathrm{He}}$ & $\begin{array}{l}\text { Opuntia } \\
\text { cactus }\end{array}$ & $i$ & Nopal & $1578^{\text {На }}$ & & \\
\hline Ipomoea batatas L. & 1753 & Camotli $^{\mathrm{He}}$ & Sweet potato & $1842^{\text {На }}$ & Camote & $1842^{\text {На }}$ & & \\
\hline Capsicum annuum L. & 1753 & Chilli $^{\mathrm{He}}$ & Chilli, pepper & $1662^{\mathrm{Ha}}$ & Chile & $1662^{\text {На }}$ & & \\
\hline Pachyrhizus erosus L. & 1753 & Xicamatl $^{\mathrm{He}}$ & Yam bean & $i$ & Jícama & $1604^{\mathrm{Ha}}$ & & \\
\hline Helianthus annus $\mathrm{L}$. & 1753 & Chimalacatl ${ }^{\mathrm{He}}$ & Sunflower & $i$ & Girasol & $i$ & & \\
\hline
\end{tabular}




\section{Agricultural Research \& Technology: Open Access Journal}

\begin{tabular}{|c|c|c|c|c|c|c|c|c|}
\hline Sechium edule Jacq. & 1760 & Chayotl $^{\mathrm{He}}$ & $\begin{array}{l}\text { Vegetable } \\
\text { pear }\end{array}$ & $i$ & Chayote & $1884^{\mathrm{Ha}}$ & & \\
\hline Phaesolus vulgaris $\mathrm{L}$. & 1753 & $\mathrm{Etl}^{\mathrm{He}}$ & Bean & $i$ & Frisol, frijol & $1542^{\mathrm{Me}}$ & & \\
\hline Cucurbita pepo L. & 1753 & Ayotl $^{\mathrm{He}}$ & Pumkin & $i$ & Calabacita & $1542^{\mathrm{Me}}$ & & \\
\hline \multirow[t]{2}{*}{ Amaranthus hybridus } & 1753 & Huautli $^{\mathrm{Me}}$ & Amaranth $^{\text {wa }}$ & $i$ & Bledo & $1542^{\mathrm{Me}}$ & Alegría & $1698^{\mathrm{SA}}$ \\
\hline & & & & & & & Amaranto & $1832^{\mathrm{Wa}}$ \\
\hline Hyptis suaveolens (L) Poit & $1806^{\mathrm{T}}$ & Chianzotzott ${ }^{\mathrm{He}}$ & & & Chia de colima & $1887^{\mathrm{Ur}}$ & Chan & $1886^{\text {Ro }}$ \\
\hline Chenopodium nuttalliae & 1753 & Huauquilitl ${ }^{\mathrm{He}}$ & & & Huauzontle & $1888^{\mathrm{Ga}}$ & & \\
\hline
\end{tabular}

Source: HaHaugen [21]; MeMendoza [25]; GaGarcía [66]; 'Tropicos [56]; SASauer [67]; WaWashington [68]; RoRodríguez [69]; UrUrbina [34]; ${ }^{\mathrm{HeH}}$ Hernández [27]; vuVuskan et al. [51].

\section{Chian, the Birth Name of the Modern Chia Crop Given by the Mexics Peoples}

In Ancient Mexico, or pre-Hispanic times, the chia crop was known as Chian [25-28], and prior to Spain porting at the naval yards in Mexico, chia along with corn, bean and amaranth were key crops for consumption. However, while chia was lower on the list of most important food crops, in ancient times it was a mainstay in offerings during routine rituals to their many holy gods [29], and its pressed oil was widely used to decorate handcrafts sold at the local fair [30]. Chia is derived linguistically from the Nahua term "Chian" which in Mexica language means "oily", and still today although considered a pseurocereal, chia is best known as an oilseed $[7,31]$. Based on this grammatical nomenclature as an adjective suggested the Mexica people referred to all species of the genus Salvia as chian [32].

As such, the chia seed available today was ultimately selected for the distinctive high oil content characteristic (S. polystachya O., S. tiliifolia V., and S. columbariae B.), although specifically, it seemed chian was mostly used to refer directly to the $S$. mexicana species that the Mexica culture domesticated prior to $15^{\text {th }}$ Century A.D.. According to Mendoza Codex records, during the preHispanic years in the capital of the Mexica Empire Tenochtitlan the demand for chia consumption ranged between 4-15-thousand-ton year -1 [25]. Then, the literature published between years 1542 and 1890 suggests that once Spain colonized Mexico the chian term continued to be used to refer the chia crop [26,27] and the last book reference where this name is used was published by Vetancourt [28].

\section{Botanist Carl Linnaeus Improperly Names the Chia Plant Salvia hispanica}

As part of the standardization of the scientific language used for identifying and classifying plants around the world, in 1753 Carl Linnaeus assigned Salvia hispanica to the chia plants found across the world [33]. This Latin binomial name had been the standard scientific name used worldwide to refer to the chia crop. However, it came to pass that this S. hispanica L. annotation presented two main inconsistencies. First, according to Linnaeus this name made relevant the geographical origin by pointing to Spain and Italy; "Salvia hispanica" translated into English is "A Spanish plant to cure or save." However, we know with certainty that the geographic origin is not Spain and/or Italy since chia cannot grow in these countries due to climactic factors; even soft frosts can kill the chia plant before it is able to flower and produce seeds $[19,34]$. Interestingly, according to Urbina [34] \& Fernald [20], Christopher Columbus carried the chia crop from Mexico to Spain for testing its environmental suitability. This assumption is consistent with the botanical work published by Gilii \& Xuarez [35], in which they classified chia as a crop that had been introduced to Rome, Italy.

Secondly, according to López [36], the botanist Pehr Löfling had collected identical-looking chia plants throughout Madrid, Spain and decidedly called it Salvia hispanica; then his mentor Professor Linnaeus used this exact Latin binomial name to denote chia in his Species Plantarum book [9]. This mean that it was Löfling, and not Linnaeus who classified chia the first time. Over time, these two contradictions came to surface such that they were widely and openly discussed in the research community. The opponents to the name $S$. hispanica L. continued to raise their point on the use of the term hispanica as the standard species name, particularly at a time when all assumptions on the species origin of chia seemed to originate in southern Mexico [37-41]. Moreover, it was in [19], by de la Llave, and then again in [34], by Urbina, who both highly suggested to change the current scientific name based on their research [33]. Despite their substantial and significant findings, the correction of the scientific and common name was never brought to public vote. In part, this was possibly due to the weight that Linnaeus exerted on the scientific community, even 80 years after his published denomination and 1753 ennoblement. As shown below, the long-sought after correction was not made until 2012.

\section{Chia, and not Chian, is the Common Name Assigned by the Academy of the Spanish Language}

The changes in the nomenclature of chia did not end with the assignment of its scientific name by Linnaeus in [9]. By the end of the $18^{\text {th }}$ century, some botanists began to use the term chia instead of chian in their published works [35,42]. More than 100 years later in Mexico, de Bustamante [43], published a list of 61 Mexican native plants on which chia as listed, and included the Nahua, Spanish and Latin binomial names which were Chian, Chia and Salvia chia, respectively. Soon after in 1832, the Spanish Language Academy decided to switch the common name back to the more modern name Chia rather than Chian [21]. By the 


\section{Agricultural Research \& Technology: Open Access Journal}

mid-1800s actions like these helped to standardize the many different dialects of Spanish into a single, common language for all worldly Spanish-speaking regions. However, according to Maisch [40], Gardner \& Holdt [44], this action caused confusion among rising plant researchers unfamiliar with the deep history, technical language of botany, and some of them began to call the many different species of the genus Salvia collectively as chia (S. columbariae B., S. mexicana, S. polystachya 0 ., S. tiliifolia V.). The confusion began to intensify when it became clear that chia was being used for plants of non-Salvia genus species such as amaranth (Amaranthus hypocondriacus) [17]; chan (Hyptis suaveolens) [15], plantago (Plantago psyllim) [14], and huazontle (Chenopodium nuttalliae) [16]. The use of the word chia used to describe at least four distinct plants throughout history was perhaps a result of the comings and goings of the Spanish brigades landing in Mexico who were apparently unassuming of the ancient terms and correct botanical usage [7], but according to Sosa-Baldivia et al. [32], there is no scientific evidence to support this hypothesis. Regarding amaranth as an aside, in the Codex of Mendoza [25], there is indication that the Spanish knew quite well of this plant and its uses, and so this ancient grain and leafy green vegetable species and the other amaranth plants were in Spanish language terms collectively called Bledo (pig weed). Therefore, it becomes clear that the Spanish way of thinking on the epistemology of deriving nomenclature of crops was to consider a single name for a collective range of crops or plants that could be grouped together using a particular inherent characteristic and/or usage for largescale production. On the other hand, but in a similar matter to the amaranth was plantago (also called psyllium or zaragatona). The Spaniards also had this plant well-differentiated from the others, and so they called it zaragatona $[34,38,40,41]$. The incorrect use of the term chia for plantago was perhaps initiated after its inclusion into the 1832 edition of the Spanish dictionary [21]. Definitive proof of this claim is made in the description that Cobo [45], made about the chia plant, in which he describes in writing that the Mexicans consumed the vegetative tissues and that the floral inflorescence is like the inflorescence of the ancient grain quinoa (Chenopodium quinoa Willd.), and surprisingly used the sesame seed to describe chia seed even though the latter is smaller than the former. From this also, it becomes clearer that Cobo had also confused the chia plant with the huauzontle plant (Chenopodium nuttalliae); which is consumed only as a fresh staple and its mature plant structure and seed are like quinoa. Thereby, this is the reason today that both huauzontle and quinoa are classified as species within the Chenopodium genus. The term chia was not only used for different species within the Salvia genus, but also with two other non-related plants chan, amaranth and plantago. In summary, the use of "chia" for multiple, different plant species added to the confusion that remained the crux of contention on the exact scientific and common nomenclature for more than 400 years.

\section{Salvia chia Fern. is chia that Originated in Mexico}

Once the common word Chia was annexed to the Spanish dictionary its public acceptance had already been widely disseminated. However, since the mid-18 ${ }^{\text {th }}$ century this was not the case for its Latin binomial name as each new binomial assignment came present caused a lot of controversy. Considering the possibility that the binomial name assigned by Linnaeus in [9] was wrong, Pablo de la Llave [19], proposed to change it to Salvia chian; and even considered an alternative species name to highlight further its Mexican origin as S. nezahualia [34]. Nevertheless, the Salvia chian name had already taken place and more so had already been accepted and used by researchers of the time $[34,46]$. Chia's long naming history continued well into the beginning of the $20^{\text {th }}$ century when Fernald presumed accurately, and so assigned its species name as chia, to indicate this Salvia crop is native to southern Mexico. In a related manner, this new scientific assignment (Salvia chia) correlated to the geoorigination research work done by Vavilov [47]. Although, any international effort to officially change chia's species name during the next decade to something other than hispanica did not reach popular consensus among the scientific community.

\section{Salba, a Novel Common Name for chia Assigned by the Peruvian Agrisalba SA Company}

The drastic reduction of the Mexican population caused by the dominating Spanish military coincided with the near-extension of chia as a lesser staple food [8]. After the Mexican population rebounded in size chia unfortunately did not recover its status as a mere secondary ingredient in food or downstream processing and manufacturing in Mesoamerica. Notably, according to Small [30], around the mid- $19^{\text {th }}$ century chia had become an exotic seed; used only to make a refreshing drink, and its pressed seed oil was again used as a type of paint solvent to be able to colorfully decorate artisan handcrafts and moreover, making terracotta pottery and figurines such as the popular Chia pets in America and globally since the late-1970s. From 1893, chia started to resurge as a main staple crop such that by 1932 (a year after Vavilov published his work) the Ministry of Agriculture in Mexico reported a cultivation size of 38 hectares [48]. It is quite easy to assume that if all the misleading information on the scientific name had not happened, and alternatively scientific investigations on chia advanced further along with other crops like corn, bean and tomato such that the government and scientific community had knowledge of the nutritional value of the polyunsaturated fatty acids like Omega-3 (found in chia) has on the human diet, indeed, chia would have been grown on a much larger scale, and heavily invested in production and modern agricultural technologies then, as it is today [33]. Global-scale chia production was not fully integrated into the modern era and non-Mexican societies until circa 1991, through an international project known as the "Northwestern Project" supported by the United States of America to help Argentina's low GDP-contributing agricultural sector [7]. The implementation of the agricultural technology generated through this long-term project had great impacts on the status quo of chia internationally as a crop of México.

While Mexico was the lead chia producing country prior to 1990 by 1992 only 500 hectares of chia were being produced 
[33]. Nearly two decades later by 2014 the chia production area had soared to 370,000 hectares [49], and according the Purechia [50], currently, this seed for oil and nutrition-valued crop is cultivated in 33 countries (Figure 1). A key fact that promoted chia consumption globally was Agrisalba SA's marketing strategy that it had implemented in 2006. It is important to note that this Peru-based company not only patented their own white chia seed varieties (Sahi Alba 911, and Sahi Alba 912), but also claimed that their white seed contains a higher nutritional value than the black chia seed produced from the Mexican cultivars "Pinta Acatic" and "Black Puebla" [32]. They even went as far as to introduce 'Salba' publicly as a new common name for their white chia seed [51]. However, Sosa-Baldivia et al. [8], affirmed that the marketing strategy used by Agrisalba SA has no scientific support because the results on the comparison of the nutritional profiles of both phenotypes does not support a higher nutritional superiority in Salba versus black chia [10,52-54].

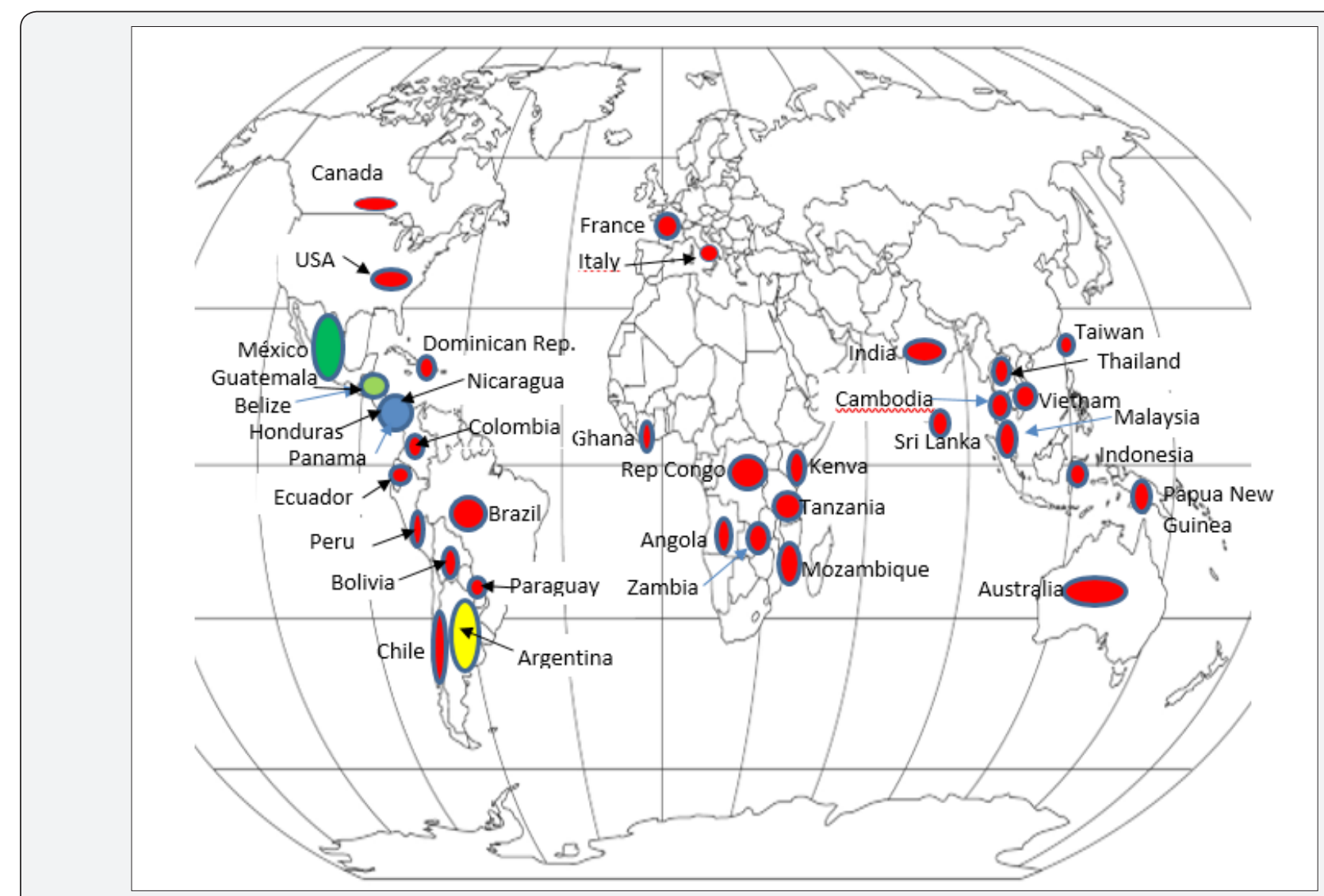

Figure 1: Historical widespread of chia crop around the world. The agricultural areas shaded in green, blue, yellow and red represent the area of chia cultivated on Early pre-Columbian times (3500 BC-1000 AC); Late pre-Columbian times (1000AC-1500 AC); Post Columbian times (1500 AC- 2000 AC); and Modern times (2010-present), respectively.

Salvia mexicana is the Currently (2012-Present) Accepted Binomial Name for Chia

The chia crop had adopted several names during the past 500 years, and most of these names can be traced back in history through literature, as described above. Finally, a significant event in the history of chia was the favorable decision to restore its Mexican identity, and is currently upheld by several international agencies, societies, botanical gardens and seed repositories specializing in plant botany, taxonomy and research [22,55-57]. For this reason, since March 23, 2012, Salvia mexicana was made the official scientific name, and acknowledged its geographical origin to present day Mexico. Since then, renowned herbariums around the world have already implemented this new nomenclature. For example, the change taking place at the Missouri Botanical Garden [56], one of the largest botanical gardens in the world, has corrected all records related with the chia plant, and even the Salvia hispanica Linnaeus nomenclature. This change in the standard nomenclature for chia coincided with the change for tomato also made by the scientific community (ca. April 18, 2012) to accept Solanum lycopersicum that Linnaeus had assigned to it in [9], effectively replacing the Latin binomial Lycopersicum esculentum denoted by Phillip Miller in 1768, as the official scientific name [56]. However, unlike for S. mexicana the use of the scientific binomial for tomato was immediate, and readily implemented in newly published scientific research papers [5863]. This immediate acceptance and use could be due to tomato as a designated and well-accepted plant research model crop like Arabidopsis. However, all research papers on chia published in many different international journals after the official acceptance of $S$. mexicana [10-12,33,64,65], did not fully implement the newly designated scientific name. Considering this important point, this 
review can be used as a source of information to reiterate to the scientific community and researchers studying or including chia in their studies that Salvia mexicana is the internationally-accepted scientific binomial name for all chia. After 265 years of Mexican heritage misunderstandings and misinformation in the botanical history of this ancestral food crop and ancient grain has endured many an adversity to finally bear its true name as "A Mexican plant to cure or save" [66-70] (Table 2).

Table 2: Historical timeline, nomenclature and antecedent on the common and scientific annotation changes of the Chia plant.

\begin{tabular}{|c|c|c|c|}
\hline Period & Nomenclature & Antecedent & Source \\
\hline Before 1550 & Chian & $\begin{array}{l}\text { In pre-Hispanic times, the chia was known as chian, after } \\
\text { the Spaniards conquered Mexico, they continued to use this } \\
\text { term to refer to this specie. }\end{array}$ & Mendoza [25] \\
\hline $1551-1698$ & Chian & $\begin{array}{l}\text { According to the published literature, while being colonized } \\
\text { by Spain, chian continued to be used to refer to the Mexican } \\
\text { chia variety. }\end{array}$ & Hernandez [27]; Farfan [26]; Vetancourt [28] \\
\hline 1753-Present & $\begin{array}{l}\text { Salvia hispan- } \\
\quad \text { ica } \mathrm{L} .\end{array}$ & $\begin{array}{l}\text { In } 1753 \text {, Carlos Linnaeus named chia using the scientific } \\
\text { nomenclature (Latin binomial) Salvia hispanica. This name } \\
\text { still is widely-accepted and used among the scientific com- } \\
\text { munity during this period. }\end{array}$ & Linnaeus [9] \\
\hline 1832-Present & Chia & $\begin{array}{l}\text { Since } 1784 \text {, some authors began to use the term chia } \\
\text { instead of chian. In } 1832 \text {, the Spanish language dictionary } \\
\text { used the colloquial word Chia to replace the fading Chian } \\
\text { word. Chia is the common name of } S \text {. hispanica during this } \\
\text { period. }\end{array}$ & $\begin{array}{l}\text { Quer \& Gomez [42]; Gilii \& Xuarez [35]; Haugen } \\
\text { [21] }\end{array}$ \\
\hline $1832-1887$ & Salvia chian Ll. & $\begin{array}{l}\text { Taking into account that the Mexican chia plant cannot } \\
\text { adapt to Spain's climate and so cannot survive, Pablo de la } \\
\text { Llave surmised that it was a novel species of chia, and so he } \\
\text { called it Salvia chian. }\end{array}$ & De la Llave [19]; Urbina [34] \\
\hline $1900-1931$ & Salvia chia Fer. & $\begin{array}{l}\text { At the turn of the } 20^{\text {th }} \text { century, botanist Merritt L. Fernald } \\
\text { renamed this chia specie } S \text {. chia, perhaps making it in-line } \\
\text { with the modern Mexican dialect. Then, Nicolas I. Vavilov } \\
\text { solidified the use of } S \text {. chia to refer to the Mexican native } \\
\text { chia specie which he demonstrated had ancestral ties to the } \\
\text { overlapping region between present Mexico and Guatemala, } \\
\text { and so is the center of origin this chia species. }\end{array}$ & Fernald [20]; Vavilov [47] \\
\hline 2006-Present & Salba & $\begin{array}{c}\text { In 2006, selection of white chia seed produced from the } \\
\text { Mexican chia variety Pinta Acatic by the natural ingredient } \\
\text { company Agrisalba S.A. were named and patented as 'Sahi } \\
\text { Alba 911' and 'Sahi Alba 912'; and, widely-marketed chia as } \\
\text { 'Salba'. }\end{array}$ & Vuskan et al. [51]; Salba [70] \\
\hline 2012-Present & $\begin{array}{l}\text { Salvia mexi- } \\
\quad \text { cana } \mathrm{L}\end{array}$ & $\begin{array}{l}\text { As of March 23, 2012, Salvia mexicana replaced Salvia his- } \\
\text { panica L. as the scientific binomial name; instituted by the } \\
\text { International Plant Name Index (INPI) and assigned to all } \\
\text { Mexican chia plants produced globally. }\end{array}$ & IPNI [22] \\
\hline
\end{tabular}

\section{References}

1. Perales HR, Aguirre JR (2008) Biodiversidad humanizada: In: Capital natural de México, vol. I: Conocimiento actual de la biodiversidad. CONABIO. D.F., México, pp. 565-603.

2. Villarreal Z, García-Marin D, Colunga P (2008) El origen de la agricultura, la domesticación de plantas, y el establecimiento de corredores biológicos culturales en Mesoamérica. Revista de Geografía Agrícola 41: 85-113.

3. Hernández BJE, León VJ (1994) Neglected crops: 1492 from a different perspective. Plant production and Protection series no 26. FAO. Rome, Italy, p. 348.

4. Pool A, Knapp S (2011) Lamiaceae. Flora Mesoamericana 4(2): 1-195.

5. Gutiérrez TR, Ramírez MLV, Vega SL, Fontecha J, Rodríguez LM, et al. (2014) Contenido de ácidos grasos en semillas de chía cultivada en cuatro estados de México. Revista Cubana de Plantas Medicinales 19(3): 199-207.
6. Sosa-Baldivia A, Ruíz-Ibarra G (2017) La disponibilidad de alimentos en México: un análisis de la producción agrícola de 35 años y su proyección para 2050. Papeles de Población 23(93): 207-230.

7. Ayerza R, Coates W (2007) Chía, redescubriendo un olvidado alimento de los Aztecas. Ed. Del nuevo extremo S.A. Buenos Aires, Argentina, pp. 232.

8. Sosa-Baldivia A, Ruiz-Ibarra G, Robles-de la Torre RR, Gordillo-Sobrino G, Sharma M, et al. (2017) La chía mexicana (Salvia hispanica L.): su historia e importancia como cultivo mundial: In: Jarquin-Galvez R, Huerta-de la Peña A (Eds.), La agricultura sostenible como base para los agronegocios. Primera edición. SOMAS. D.F, México, pp. 1504-1555.

9. Linnaeus C (1753) Species Plantarum Sections I-III. pp. 127.

10. de Falco B, Amato M, Lanzotti V (2017) Chia seeds products: an overview. Phytochem Rev 16(4): 745-760.

11. Ramirez JJ, Lozano MGC (2015) Potential for growing Salvia hispanica L. areas under rainfed conditions of México. Agricultural Sciences 6(9): 1048-1057. 
12. Muñoz AL, Cobos A, Díaz O, Aguilera JM (2013) Chia seed (Salvia hispanica): An ancient grain and a new functional food. Food Reviews International 29(4): 394-408.

13. Jamboonsri W, Phillips TD, Geneve RL, Cahill JP, Hildebrand DF (2012) Extending the range of and ancient crop (Salvia hispanica L.) -a new omega3 source. Gen Resour Crop Evol 59(2): 171-178.

14. Ramirez J, Alcocer GV (1902) Sinonimia vulgar y científica de las plantas mexicanas. Oficina Tipográfica de la Secretaria de Fomento. DF México, pp. 160.

15. Alvarado RID (2011) Caracterización de la semilla de chan (Salvia hispanica L.) y diseño de un producto funcional que la contiene como ingrediente. Revista de la Universidad del Valle de Guatemala 23: 4349.

16. Kistler L, Shapiro B (2011) Ancient DNA confirms a local origin of domesticated chenopod in eastern. Journal of Archeological Science 38(12): 3549-3554

17. García AJM, de la Cruz ET (2016) Las chías de México. ININ. Contacto Nuclear 14-18.

18. Rangaraju A, Mohan UK (2013) A Pharmacognostic Study on Salvia Hispanica. AJPHR 1(9): 27-37.

19. de la llave P (1833) Sobre una nueva especie diferente de Salvia. Registro Trimestre pp. 441-448.

20. Fernald LM (1900) A sinopsis of the Mexican and Central American species of Salvia. Proceedings of the American Academy of Arts and Sciences 35(25): 489-556.

21. Haugen DJ (2009) Borrowed Borrowings: Nahuatl Loan Words in English. LEXIS Journal in English Lexicology 3: 63-106.

22. International Plant Name Index (IPNI) (2018) Lamiaceae, Salvia Mexicana L.

23. Gayathiri K, Sangeetha M, Sharanya VK, Shyam Prakash G, Vimalavathini R, et al. (2016) A Review: Potential Pharmacological Uses of Natural Products from Laminaceae. International Journal of Pharma Research \& Review 5(5): 21-34.

24. Walker J (1999) Hibiscus. Cassel, London, England.

25. Mendoza A (1542) Códice Mendocino. pp. 150.

26. Farfán A (1610) Tratado breve de medicina y de todas las enfermedades. Emprenta Geronymo Balli. Mexico, pp. 261.

27. Hernandez F (1615) Qvatro libros de la natvraleza y virtvdes de las plantas, y animales que eftan receuidos en el vfo de la medicina en la Nueua Efpaña. Casa de la viuda de de Diego Lopez Davalos. Calle de Tacuba, Mexico, pp. 407.

28. Vetancourt A (1698) Teatro Mexicano. Tomo I. Biblioteca Histórica de Iberia, México, pp. 512.

29. Montúfar LA (2007) Las chías sagradas del Templo Mayor de Tenochtitlan. Arqueología Mexicana 14(84): 82-85.

30. Small E (2011) 34. Chia- Not just a pet. Blossoming treasures of diversity. Biodiversity 12(1): 49-56.

31. Cahill JP (2003) Ethnobotany of chia, Salvia hispanica L. (Lamiaceae). Economic Botany 57(4): 604-618.

32. Sosa-Baldivia A, Ruiz-Ibarra G, Robles-de la Torre RR, Robles-Lopez R, Montúfar A (2018) The chia (Salvia hispanica): past, present, and future of an ancient Mexican crop. Australian Journal and Crop Research.

33. Sosa-Baldivia A, Ruiz-Ibarra G, Rana J, Gordillo G, West H, et al. (2016) Chia crop (Salvia hispanica L.): its history and importance as a source of polyunsaturated fatty acids omega- 3 around the world: a review. Journal Crop Research and Fertilizer 1: 104: 1-9.

34. Urbina M (1887) La chía y sus aplicaciones. Naturaleza 1: 27-36.
35. Gilii LF, Xuarez G (1790) Osservazioni fitologiche sopra alcune piante esotiche introdotte in Roma. Rome, Italy.

36. López JN (2007) Las plantas vasculares de la comunidad de Madrid. Catalogo florístico, claves dicotómicas y estudio detallado de la familia Compositae Giseke. Universidad Complutense de Madrid, España, pp. 409.

37. AMQP (Academia Medico Quirúrgica de Puebla) (1832) Ensayo para la materia medica mexicana. Puebla, México, p. 101

38. Guibourt G (1849) Semence de chia. Journal Pharmacie et de Chimie 15: 260 .

39. Orozco BM (1856) Apéndice al diccionario universal de historia y geografía. Colección de artículos relativos a la República Mexicana. Tomo II, IX de la obra. Imprenta de JM Andrade y F Escalante. México, p. 936.

40. Maisch MJ (1882) On chia and allied species of Salvia. American Journal of Pharmacy 54: 229- 234.

41. Soubeiran L (1887) Etude de la semence de chia. Journal Pharmacie et de Chimie 15-16: 260-265.

42. Quer J, Gomez de OC (1784) Continuación de la flora Española o historia de las plantas de España. Tomo VI. Madrid, España.

43. de Bustamante MC (1830) Historia general de las cosas de la Nueva España que en doce libros escribió el RP. Fray Bernardino de Sahagun. Tomo Tercero. Imprenta del ciudadano Alejandro Valdez. Calle de Santo Domingo y Esquina de Tacuba. Mexico.

44. Gardner AH, PC Holdt (1920) A novel drying oil chia oil (Salvia hispanica). Circular No. 105. Paint Manufacturers Association of the U.S. October: 1-8.

45. Cobo B (1890) Historia del Nuevo mundo. Tomo 1. Publicado por primera vez con notas e ilustraciones de Marcos Jiménez de la Espada. Sociedad de Bibliófilos Andaluces. Sevilla, España, p. 530.

46. Garcia CA (1893) México its trade, industries and resources. Office of Department of Foment, Colonization and Industry, México. p. 436.

47. Vavilov IN (1931) México y Centroamérica como centro básico de origen de las plantas cultivadas del nuevo mundo. Revista de Geografía Agrícola 20: 15-34.

48. Rulfo JM (1937) La chía. Agricultura 1: 28-37.

49. Peperkamp M (2015) CBI Tailored Intelligence: chia from Bolivia 'a modern super seed in a classic pork cycle? CBI Ministry of Foreign Affairs. The Hague, Netherlands, p. 16.

50. Purechia (2013) Rich Source of Omega-3, Protein, Fiber \& Antioxidants. Next Big Thing in Food.

51. Vuksan V, Jenkins AL, Dias AG, Lee AS, Jovanovski E, et al. (2010) Reduction in postprandial glucose excursion and prolongation of satiety: possible explanation of the long-term effects of whole grain Salba (Salvia Hispanica L.). Eur J Clin Nutr 64(4): 436-438.

52. Ayerza R (2013) Seed composition of two chia (Salvia hispanica L.) genotypes which differ in seed color. Emirates Journal of Food and Agriculture 25(7): 495-500.

53. Bueno M, González M, Quiroga M, Severin C, Busilacchi H (2016) Caracterización de semillas blancas y negras de Salvia hispanica L. (Lamiaceae) Agromensajes 46: 1-7.

54. Cassiday L (2017) Chia: superfood or superfat. INFORM 28(1): 6-13.

55. Herbarium Catalogue, Royal Botanic Gardens Kew (HCBGK) (2018) Lamiaceae, Salvia mexicana.

56. Tropicos (2018) Lamiaceae, Salvia mexicana L.

57. WCSP (World checking List of Select Plants Families) (2018) Salvia mexicana L. Facilitated by the Royal Botanic Gardens. 
58. Leyva-Mir SG, Gonzalez-Solano CM, Rodríguez-Pérez JE, MontalvoHernández D (2013) Comportamiento de líneas avanzadas de tomate (Solanum lycopersicum L.) a fitopatógenos en chapingo, méxico. Revista Chapingo Serie horticultura 19(3): 301-313.

59. Sánchez-Del Castillo F, del C Moreno-Pérez E, Pineda-Pineda J, Osuna JM, Rodríguez-Pérez JE, et al. (2014) Hydroponic tomato (Solanum lycopersicum L.) production with and without recirculation of nutrient solution. Agrociencia 48: 185-197.

60. Berrospe-Ochoa AE, Saucedo-Veloz C, Ramírez-Vallejo P, RamírezGuzmán ME (2015) Comportamiento agronómico de plántulas de poblaciones nativas de jitomate (Solanum lycopersicum L.) en producción intensiva en invernadero. Agrociencia 49(6): 637-650.

61. Gabriel J, Angulo A, Velasco J, Guzmán R (2016) Adaptación de híbridos de tomate indeterminado [Solanum lycopersicum L. (Mill.)] bajo condiciones de invernadero. J Selva Andina Res Soc 7(2): 47-65.

62. Boudet AA, Boicet-Fabré T, Durán-Ricardo S, Meriño-Hernández Y (2017) Efecto sobre el tomate (Solanum lycopersicum L.) de diferentes dosis de abono orgánico bocashi en condiciones agroecológicas. Revista Centro Agrícola 44(4): 37-42.

63. Banihani AS (2018) Tomato (Solanum lycopersicum L.) and type 2 diabetes. International Journal of Food Properties 21(1): 99-105.
64. Ayerza R (2014) Chia flowering season prediction using day length data of 11 selected locations. Rev Ind Agríc de Tucumán 91(1): 33-35.

65. Onneken P (2018) Salvia hispanica L (Chia Seeds) as Brain Superfood: How Seeds Increase Intelligence. J Nutr Food Sci 8: 2.

66. Garcia CA (1888) Diccionario geográfico, histórico y biográfico de los Estados Unidos Mexicanos. Tomo 1-3. Antigua Imprenta de Murguia. México, pp. 408.

67. Sauer DJ (1950) The Grain Amaranths: A Survey of Their History and Classification. Annals of the Missouri Botanical Garden 37(4): 561-632.

68. Washington WE (1832) Flora's dictionary. University of California, USA, p. 192.

69. Rodríguez I (1886) Ensayo geográfico, estadístico e histórico del estado de Colima: formado de orden del gobernador del mismo C. Esteban García, en vista de los datos más fehacientes, tanto oficiales como privados. Imprenta del Gobierno del Estado de Colima. Colima, México, pp. 87.

70. Salba (2018) Salba chia vs regular chia.

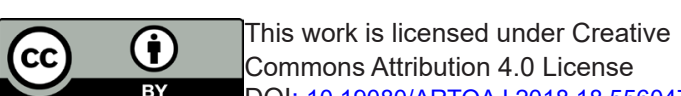
Commons Attribution 4.0 License
DOI: 10.19080/ARTOAJ.2018.18.556047

\section{Your next submission with Juniper Publishers will reach you the below assets}

- Quality Editorial service

- Swift Peer Review

- Reprints availability

- E-prints Service

- Manuscript Podcast for convenient understanding

- Global attainment for your research

- Manuscript accessibility in different formats

(Pdf, E-pub, Full Text, Audio)

- Unceasing customer service

Track the below URL for one-step submission https://juniperpublishers.com/online-submission.php 